\title{
Emphasis of University Supervisor Feedback to Teacher Candidates
}

\author{
Valentina Vertemara $^{\mathrm{a}}$ and Tanya Flushman ${ }^{\mathrm{a}}$
}

The purpose of this study is to analyze the emphasis of the feedback that university supervisors give to teacher candidates. Specifically, we seek to understand the relation of praise versus area of growth and how the emphasis relates to the focus of feedback. Data included coded observation reports from eight university supervisors. The three main findings were: praise feedback had a significantly higher amount than area of growth feedback, feedback emphasized certain skills over others, and a significant portion of feedback was neutral in nature. These findings have implications for teacher preparation and the process for providing written feedback to teacher candidates. They include thoughtful consideration of the nature of constructive and comprehensive feedback in teacher preparation and the importance of candidates receiving a variety of feedback across the pedagogical skills necessary to be an effective teacher.

Keywords: University Supervisor, Teacher Candidate, Feedback, Emphasis of Feedback

The student teaching experience, also referred to as clinical practice, is one of the major steps that all future teachers must go through before entering the classroom. It gives the future teacher a chance to apply the theoretical concepts learned in the college classroom to the elementary school classroom. Throughout this experience, the future teacher, also known as the teacher candidate (TC) interacts with two people: the cooperating teacher (CT) and the university supervisor (US). Together, these three members form a triad whose purpose is to guide the teacher candidate throughout the student teaching process. An essential part of this guidance is the feedback given to the teacher candidate by the cooperating teacher and university supervisor. This feedback allows the teacher candidate to learn and improve teaching skills and practices. Although both these roles are fundamental to the teacher candidate's experience, there is a lack of clarity around the purpose and function of the university supervisor's role that can interfere with the feedback given to the teacher candidate. One area of feedback that is particularly influenced by this insufficient clarity of the role is the emphasis of university supervisor feedback-whether the feedback given was praise or an area of growth. This study seeks to better understand the nature of feedback given by university supervisors so as to inform any changes to clinical practice that may better support teacher candidate development.

\section{The Importance of University Supervision}

The university supervisor is an important member of the teacher candidate's experience (Zahorik, 1988; Slick, 1988). It is important for university supervisors to visit the elementary classrooms because teacher candidates spend more time in the field than in the university classrooms (Levine, 2011; Richardson-Koehler, 1988). The university supervisor is the connection from the elementary schools to the university. They ensure that the elementary school is providing a well-structured and safe environment for the teacher candidates, and that the university is sending well-prepared teacher candidates to teach the elementary school's students (Slick, 1998). Finally, the university supervisor has an important job because they must be able to take on diverse and sometimes contrasting roles in order to best prepare the teacher candidate for a real-world teaching position (Slick, 1998; Zimpher, \& DeVoss, 1980).

\section{The University Supervisor's Role}

The university supervisor's role is extremely complicated and complex due to the lack of clarity of their role and the lack of support from the university. Although some definitions are provided for the role of the university supervisor, the supervisors themselves often do not know what their job consists of (Slick, 1998; Slick, 1997; Bates, \& Burbank, 2008). Three university supervisors were interviewed across three different qualitative case studies. All three university supervisors were female graduate students who felt that their universities did not define their roles and responsibilities. Therefore, they found themselves in many situations in which they did not know how to respond or react. This lack of clarity in the university supervisor role leads to three main problems for the university supervisor: insecurity with holding authority, fear of confrontation with the teacher candidate, and difficulty in setting expectations for the teacher candidate.

One of the university supervisors in Slick's study, along with another supervisor in Richardson-Koehler's qualitative case study, expressed their insecurity with holding authority (Slick, 1998; Richardson-Koehler, 1988). There were two main reasons for this. First, the graduate student university supervisor did not know her role and what was expected out of her, so she felt uncomfortable being the authoritative figure when she herself did not know what should be done (Slick, 1998). Secondly, the university supervisor stated that she specifically felt troubled when giving feedback to the teacher candidate because she was afraid that by doing so she would be disrespectful to the cooperating teacher (Richardson-Koehler, 1988). This supervisor felt as though she were not enough of an authoritative figure when compared to the cooperating teacher and therefore felt uneasy when trying to complete a very important aspect of her role.

The lack of definition of the university supervisor role also impacts the relationship between university supervisor and teacher candidate. Four graduate student university supervisors voiced their fear of confrontation with the teacher candidates (Slick, 1997; Borko, \& Mayfield, 1995). The supervisors wanted to maintain a friendly and positive relationship with their teacher candidates. However, this can cause problems when it comes time for the university supervisor to give constructive criticism to the teacher candidate. University supervisors feel as if giving constructive criticism is a negative

a. School of Education, California Polytechnic State University, San Luis Obispo, CA, 93407

Correspondence: Valentina Vertemara vvertema@calpoly.edu

Dr. Tanya Flushman Assistant Professor of Elementary Literacy Education tflushman@ calpoly.edu 
affair and this has the potential to interfere in the coaching and evaluative process.

Finally, the lack of clarity of the university supervisor role contributes to the difficulty in setting expectations for the teacher candidates. Zimpher and DeVoss (1980) state in their study that part of the role of the university supervisor is defining and communicating expectations to the teacher candidate. Nonetheless, teacher candidates are dissatisfied that the goals, standards, and expectations are unclear or not mentioned (Chesley, \& Jordan, 2012; Slick, 1997). A major aspect of the university supervisor's role that causes some discrepancies in the expectations for the teacher candidate is the stance, attitude or position that university supervisors take towards the teacher candidate and within their feedback (Bates, Drits, \& Ramirez, 2011; Zahorik, 1988). Two different case studies interviewed 3 university supervisors and 10 university supervisors respectively regarding their positioning. Each study produced three university supervisor positions that were comparable to each other. One position was concerned with the behavior, self-esteem and feelings of the teacher candidate, the second was more concerned with the university supervisor telling the teacher candidate what they felt was correct or appropriate in the classroom, and the third position was about the university supervisor supporting the teacher candidate and maintaining a positive relationship. The studies found that the university supervisors were aware of their position and one stated that the university supervisors were also aware of how their position influenced their practice (Zahorik, 1988; Bates, Drits, \& Ramirez, 2011). We hypothesize that the stance taken by an individual supervisor could affect the nature of their feedback (including content and balance of praise versus suggestions for growth).

The second theme that occurred throughout the study that contributed to the complexity of the supervisor's role was that university supervisor felt unsupported by the university and the other triad members (Levine, 2011; Ediger, 2009; Slick 1998). University supervisors feel as if they are the outsider in the triad (Levine, 2011; Zimpher, \& DeVoss, 1980). This feeling contributes to many of the problems described above such as the university supervisor feeling insecure about authority, and the university supervisor's fear of confrontation with the teacher candidate.

This lack of support and feeling of being an outsider was exhibited in two different ways. First, data coded from interviews across two separate studies with thirteen university supervisors ( 3 of which were graduate students) showed that the supervisors felt as if they were not well-prepared to understand and provide feedback regarding the content that was being taught by the teacher candidates (Lindahl, \& Baecher, 2016; Borko, \& Mayfield, 1995). Chesley and Jordan (2012) found that this lack of content knowledge on behalf of the university supervisor has been confirmed by a cohort of thirty new teachers with 6 months to two years of experience who reflected back on their student teaching experience. They commented that because the university supervisor was not always able to provide them with content related feedback, their content knowledge and their ability to teach content suffered (Chesley, \& Jordan, 2012).

A second issue that arose for the university supervisors due to lack of support and planning on behalf of the university is that the university supervisors feel that they do not spend enough time with the teacher candidate and observing in the classroom (Borko, \& Mayfield, 1995; Range, Duncan, \& Hvidston, 2013; Richardson-Koehler, 1988; Zimpher, \& DeVoss, 1980). Not being allotted enough time for their work caused some important consequences for the university supervisor which affected the teacher candidates' experience. In a qualitative study, five of the nine university supervisors that were interviewed admitted to not conducting preobservation conferences with their teacher candidate due to lack of time (Range, Duncan, \& Hvidston, 2013). The matter of lack of time with the university supervisor was also mentioned by fourteen teacher candidates who were interviewed in a qualitative case study (Richardson-Koehler, 1988). In fact, these teacher candidates stated that their perceptions and attitudes towards the university supervisor took on a negative tone due to the fact that they do not have enough time together in order to get to know and trust each other (Richardson-Koehler, 1988).

\section{University Supervisor feedback}

Given the complexity of the university supervisor role, what is the nature of the written feedback they provide to teacher candidates? The nebulous role of the supervisor in practice is influenced by and influences the lack of consensus from research regarding best practices for university supervision. Research tells us that there is great variation in the nature of the feedback university supervisors provide to teacher candidates (Bates \& Burbank, 2011; Bates, Drits, \& Ramirez, 2011; McAfee, Ruhl, \& Scheeler, 2004; Rathel, Drasgow, \& Christle, 2008). First, although research tells us about the importance of the immediacy of feedback (Burns, Jacobs, \& Yendol-Hoppey, 2016; Scheeler, Ruhl, \& McAfee, 2004), we know that truly providing feedback immediately after an individual teaching behavior is challenging and infrequently done. Largely, oral feedback is given after a lesson has been taught and written feedback is often received even later. Second, performance-based feedback or feedback directly related to an observed behavior has proven to be effective (Cornelius \& Nagro, 2014). Cornelius and Nagro's journal review found that $90 \%$ of teacher candidates included in the study increased their desired teaching behaviors when they received evidence-based performance feedback.

\section{Praise versus growth}

One of the most important types of feedback that university supervisors can give is constructive feedback. In fact, university supervisors agree that part of their job is to critique the teacher candidates practice in order to help them improve (Range, Duncan, \& Hvidston, 2013; Zimpher, \& Devoss, 1980). However, many university supervisors find it difficult to give this type of feedback (Bates, \& Burbank, 2008). In a qualitative case study, Bates and Burbank (2008) coded an interview conducted with the university supervisor and found that when the teacher candidate is excelling, the university supervisor tends to give individual and thorough feedback. On the other hand, when the teacher candidate is having difficulty the university supervisor gives standardbased and incomprehensive feedback. Another approach that university supervisors take when they are confronted with a struggling teacher candidate is using directive feedback. In a study conducted in the United Arab Emirates, ten university supervisors were interviewed and stated that the type of feedback they used the most is directive (Ibrahim, 2013). 
Whether this practice was effective or not was not stated however, only $9.3 \%$ of the 108 teacher candidates interviewed stated directive feedback as their preferred type of feedback. Although teacher candidates were against this type of feedback the university supervisors maintained that telling the teacher candidate what to do was the easiest way to correct their mistakes.

\section{Purpose of the Study}

Although many agree that the university supervisor's role is extremely important and relevant, it is also extremely complex and unclear. Many times, university supervisors are confused as to what their job or role entails. This can cause miscommunication and tension with the other members of the triad. The feedback that the teacher candidates are receiving from the university supervisors plays a big role in their preparation. However, as illustrated in this review, there are gaps in what we know about the feedback provided to teacher candidates. One particularly large gap in the literature presented above is regarding emphasis of the feedback. Emphasis of feedback is defined as either feedback that gives praise or feedback that explains an area of growth. In addition, we know little about what pedagogical practices (prioritized skills) are emphasized in praise and constructive feedback. To better understand the quality of the feedback given from university supervisors to teacher candidates, the following questions must be explored:

1. What is the relationship between praise versus area of growth in university supervisor feedback to teacher candidates?

2. Within each prioritized skill, what is the relationship of praise versus area of growth in university supervisor feedback to teacher candidates?

\section{Method}

\section{Context for the Study}

This study took place in a mid-sized state university in central California with a population of approximately 21,306 students and 1,439 faculty in fall 2016. This study is part of a larger study funded by an external grant in order to better investigate the clinical experience and strengthen teacher preparation through district partnership. Teacher candidates from elementary and special education participate in a yearlong program with clinical experience embedded in each quarter.

\section{Participants}

The participants of this study include eight university supervisors from elementary and special education. In all, the participants supervised 15 teacher candidates and each supervisor had between 1-3 teacher candidates. All supervisors are considered part-time lecturers and all are former/retired teachers and/or administrators.

\section{Procedures for Clinical Supervision}

In our clinical model of supervision, university supervisors must observe each teacher candidate four times per quarter. The teacher candidate sends their lesson plan to the university supervisor 24 hours before the lesson. Then the university supervisor comes to the classroom and observes the teacher candidate. After the observation, the university supervisor gives verbal feedback to the teacher candidate about the lesson. Finally, the university supervisor completes the observation report and sends one copy electronically to the teacher candidate and uploads a second copy on an online data management system.

\section{Data Source}

The data sources for this study were observation reports written by the university supervisors using an observation tool [see Appendix B]. The observation tool was created by adapting the Danielson Framework for Teaching (Danielson, 2011). The tool captures basic demographic information, numerical ratings on each of the 15 prioritized skills and an evidence section in which supervisors give more feedback about all the prioritized skills and any overall feedback about the lesson. In the final two sections, the supervisors are prompted to provide 2-3 strengths of the lesson and 2-3 suggestions for improvement.

\section{Data Collection and Analysis}

Faculty assistants took the observation reports from the online data management system and made them anonymous to ensure the accuracy of the research, and the anonymity of the participants. The faculty assistants then randomly placed the observation reports in folders which were sent to the undergraduate research assistants.

The data in this study was analyzed through the coding of individual written feedback units found within the observation reports. A feedback unit is defined as a written statement and/or question provided by the supervisor that comments on the performance of the teacher candidate. Faculty completed an initial analysis of baseline data and based on those results and on the observation tool, created a codebook [see Appendix A].

The prioritized skills are the pedagogical practices that teacher candidates are evaluated on as they progress towards completion of the program (see Figure 1). The first category called Planning and Preparation pertains to lesson design. The second category is Classroom Environment and it pertains to classroom climate, procedures, and management. The third category is Instruction and it pertains to the execution of the lesson. The fourth and final category was Professional Responsibilities and Reflection which pertains to the teacher candidates' reflective practices and professionalism.

\begin{tabular}{|c|}
\hline \multicolumn{1}{|c|}{ Pricritized Skills } \\
\hline Planning and Preparation \\
Demonstrating know1edge of students \\
Setting Instructiona1 Outcomes \\
Designing coherent instruction \\
Designing student assessments \\
Supporting EBs \\
Respect \& Rapport \\
Managing classroom procedures \\
Managing student behavior \\
Communicating with students \\
Using questioning and discussion techniques \\
Engaging students in learning \\
Using assessment in instruction \\
Supporting EBs \\
Professional Responsibitities \& Reflection \\
Reflecting on teaching \\
Professionalism
\end{tabular}

Figure 1. Prioritized Skills 
The undergraduate research assistants were then trained to code the data using the codebook and coded a total of 34 observation reports. Twenty percent of these were double coded by faculty to ensure reliability of at least $80 \%$ in the coding. The coded data was quantified and put on a spreadsheet. The overall percentages of praise and areas of growth, for each supervisor, and the percentages of praise and area of growth for each prioritized skill were then analyzed.

\section{Results}

In all, there were 1,109 evaluative units of feedback. These units were broken down into the codes: praise, area of growth, and neutral. When writing the codebook, the faculty only accounted for codes for praise and area of growth however, once coding began, a large amount of feedback was found that did not pertain to either of those codes. For example, in one observation, a university supervisor wrote, "For the next phase of the lesson, [the teacher candidate] introduced the difference between fact and opinion". This unit of feedback expresses neither praise nor an area of growth therefore, a code for neutral was created for this and similar feedback.

There were a total of 560 units of praise feedback making praise the most popular feedback given. The prioritized skill that had the highest amount of praise feedback was engaging students in learning (17.67\% of the total praise feedback). On the other hand, the prioritized skill that had the least amount of praise feedback was professional responsibilities and reflection $(0.18 \%$ of the total praise feedback). The total number of praise feedback was higher than the total number of area of growth feedback across all prioritized skills. However, when comparing the total amount of praise feedback and the total amount of neutral feedback it was found that there was more praise feedback for 13 of the prioritized skills, more neutral feedback for 4 prioritized skills and the same amount of praise and neutral feedback for 2 prioritized skills.

There were 150 units of area of growth feedback making it the category with the least number of units of feedback. Managing student behavior consisted of $23.33 \%$ of the total making it the prioritized skill with the most area of growth feedback. On the contrary, professional responsibilities and classroom environment had the least amount of area of growth feedback with 0 units of feedback for those prioritized skills. When compared to praise and neutral feedback, area of growth feedback was given the least, across $18 / 19$ prioritized skills. There were a total of 399 units of neutral feedback given. The prioritized skill that had the most neutral feedback was engaging students in learning with $29.07 \%$ of the total neutral feedback. Similarly, to the area of growth feedback category, professional responsibilities and classroom environment had the least amount of neutral feedback making up $0.25 \%$ of the total neutral feedback.

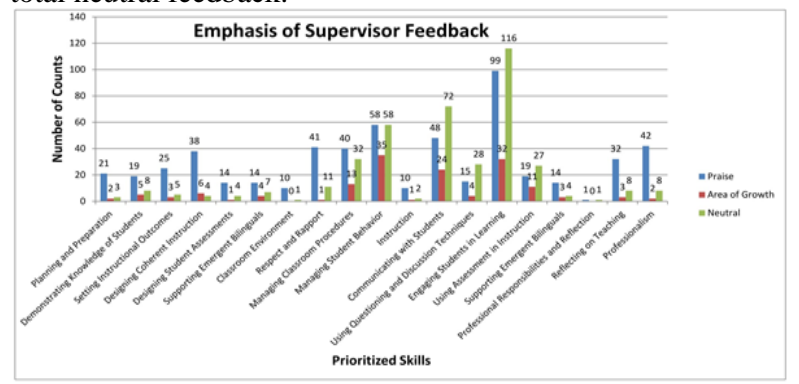

Figure 2. Emphasis of Supervisor Feedback

\section{Discussion}

Several significant points regarding the emphasis of feedback within prioritized skills in university supervisors' feedback to pre-service teachers were found in this study. First, the matter of the large difference between the amount of growth feedback and the amount of praise feedback, with amount of praise feedback being higher for every prioritized skill. Research has shown that positive feedback is effective (Scheeler, Ruhl, \& McAfee, 2004; Ilim, Inoezue \& Yildirin, 2007). University supervisors may interpret positive feedback as a synonym for praise feedback. However, area of growth feedback can be positive and corrective as well, if it is delivered in the constructive manner. Furthermore, research has proven that area of growth feedback, if delivered correctly, is both needed and wanted by teacher candidates (Scheeler, Ruhl, \& McAfee, 2004; Range, Duncan, \& Hvidston, 2013; Zimpher, \& DeVoss, 1980). We believe previously cited research can help explain this discrepancy. Although university supervisors and teacher candidates alike have expressed their favor towards area of growth feedback, there are inter-triad relationship struggles that inhibit university supervisors from giving area of growth feedback. Mainly, university supervisors are insecure of the authority they hold, they are afraid of confrontation with the teacher candidate, and they feel like an outsider compared to the other two members of the triad. Because of this, we hypothesize university supervisors steer away from giving area of growth feedback for fear that it will cause and/or amplify the problems mentioned above (Levine, 2011; Slick, 1998; Slick, 1997; Richardson-Koehler, 1988; Zimpher, \& DeVoss, 1980; Borko, \& Mayfield, 1995).

Second, the findings show that university supervisors do not provide a lot of feedback on supporting emergent bilinguals and demonstrating knowledge of students. These two prioritized skills represent the knowledge of the teacher candidate about the diversity of his or her students and how to respond accordingly to it. This is consistent with the research in that new teachers, who had gone through the student teaching process, have claimed that they were unprepared in this area by their university supervisor (Chesley, \& Jordan, 2012).

A third major finding was that the prioritized skills that received a majority of growth feedback included managing student behaviors and engaging student learning. Research explains that university supervisors believe that because teacher candidates are not experienced, they struggle mostly with these prioritized skills that they label "low-level skills" (Range, Duncan, \& Hvidston, 2013). However, because university supervisors focus so much on these low-level skills, we hypothesize they may not give as much feedback on more general prioritized skills such as respect \& rapport, reflecting on teaching, and planning and preparation (Chesley, \& Jordan, 2012).

The last and one of the most significant findings of this study was the addition of the code for neutral feedback. The existence of this type of feedback signifies that the teacher candidate must interpret these feedback units and infer if they should continue the behavior or not. This poses a problem when it comes to the university supervisor's expectations of the teacher candidate because when teacher candidates receive neutral feedback, they may be unclear of expectations (Chesley, \& Jordan, 2012; Slick, 1997; Bates, Drits, \& Ramirez, 2011). Is this a practice that they should continue with 
or abandon? However, in order for university supervisors to make clear expectations for their teacher candidates, they must in turn have clear expectations for themselves made by their university which, as research points out, is not always the case (Levine, 2011; Ediger, 2009; Slick, 1998).

\section{Implications}

The findings from this research have a potential for significant impact in the way we involve university supervisors in the process of clinical preparation. First, teacher educators should encourage the university supervisor to see themselves as one who provides praise and also constructive suggestions for growth. It is extremely important that teacher candidates know and understand what areas of their teaching need improvement in order for them to be as prepared as possible when they venture out as professional teachers. Training supervisors in how to provide suggestions for growth in a positive and constructive manner would potentially mitigate any negative influence on the relationship with the teacher candidate.

Second, university supervisors should be encouraged to expand the breadth of feedback to encompass more pedagogical practices. Future teachers need to be proficient at an assortment of practices to be effective instructorsparticularly including the ability to support emergent bilinguals. We hypothesize that if teachers receive a breadth of quality feedback they will be well-rounded and better equipped to handle all situations, including ones they may not have encountered throughout their student teaching experience.

Lastly, explicitly connecting the practice with the emphasis helps the teacher candidate better understand good practice versus practice that needs to be improved. University supervisors would benefit from professional development opportunities that help them make feedback more explicit. Feedback that clearly articulates to the reader (teacher candidate) that a practice is one they want to keep in their pedagogical tool box or a practice that should be set aside for a better one.

\section{Limitations}

The first limitation of this study is that there was little research on the topic of praise feedback and areas of growth feedback from university supervisors to pre-service teachers. We utilized this research and our own practical experience to design our own study. Second, although the same number of elementary and special education university supervisors were selected, there were more elementary observations than special education because of the respective sizes of the two programs.

\section{References}

Bates, A., \& Burbank, M. (2008). Effective student teacher supervision in the era of no child left behind. The Professional Educator, 32(2), 1-11.

Bates, A., Drits, D., \& Ramirez, L. (2011). Self-Awareness and enactment of supervisory stance: Influences on responsiveness toward student teacher learning. Teacher Education Quarterly,38(3),69-87.

Borko, H. \& Mayfield, V. (1995). The roles of the cooperating teacher and the university supervisor in learning to teach. Teaching and Teacher Education, $11,501-518$.

Burns, R. W., Jacobs, J., \& Yendol-Hoppey, D. (2016). Preservice teacher supervision within field experiences in a decade of reform: A comprehensive meta-analysis of the empirical literature from 2001-2013. Teacher Education and Practice, 29(1), 46.

Chesley, G. M., \& Jordan, J. (2012). What's missing from teacher prep. Educational Leadership, 69(8), 41-45.

Cornelius, K. E., \& Nagro, S. A. (2014). Evaluating the evidence base of performance feedback preservice special education teacher training. Teacher Education and Special Education, 37(2), 133-146.

Danielson, C. (2011). Enhancing professional practice: A framework for teaching. ASCD.

Ediger, D. M. (2009). Supervising the student teacher in the public school. Education, 130(2), 251-254.

Ibrahim, A.S. (2013). Approaches to supervision of student teachers in one UAE teacher education program. Teaching and Teacher Education, 34, 38-45.

Ilin, G., Inoezue, J., \& Yildirim, R. (2007). Successful supervision from the student teachers' perspective: An analysis of supervisory talk. Hacettepe University Education Faculty Magazine, 32, 123 129.

Levine, T. H. (2011). Features and strategies of supervisor professional community as a means of improving the supervision of preservice teachers. Teaching and Teacher Education, 27(5), 930-941.

Lindahl, K., \& Baecher, L. (2016). Teacher language awareness in supervisory feedback cycles. ELT Journal, 70(1), 28-38.

Range, B., Duncan, H., \& Hvidston, D. (2013). How Faculty Supervise and Mentor Pre-Service Teachers: Implications for Principal Supervision of Novice Teachers. International Journal of Educational Leadership Preparation, 8(2), 43-58.

Rathel, J. M., Drasgow, E., \& Christle, C. C. (2008). Effects of supervisor performance feedback on increasing preservice teachers' positive communication behaviors with students with emotional and behavioral disorders. Journal of Emotional and Behavioral Disorders, 16(2), 67-77.

Richardson-Koehler, V. (1988). Barriers to the effective supervision of student teaching: A field study. Journal of teacher education, 39(2), 28-34.

Scheeler, M.C., Ruhl, K.L., \& McAfee J.K. (2004). Providing performance feedback to teachers: A review. Teacher Education and Special Education, 27(4), 396-407.

Slick, S. (1997). Assessing versus assisting: The supervisor's roles in the complex dynamics of the student teaching triad. Teaching and Teacher Education, 13, 713-726.

Slick, S. (1998). The university supervisor: A disenfranchised outsider. Teaching and Teacher Education, 14, 821834.

Yildirim, A. (2013). Student teachers' perceptions about their education supervisors' role. Educational Research and Reviews, 8(3), 112. 
Zahorik, J. A. (1988). The observing-conferencing role of university supervisors. Journal of Teacher Education, 39(2), 9-16.
Zimpher, N. L., DeVoss, G. G., \& Nott, D. L. (1980). A

closer look at university student teacher supervision. Journal of Teacher Education, 31(4), 11-15.

Appendix A

Baseline Data Coding Scheme for University Supervisor Feedback

\begin{tabular}{|c|c|c|}
\hline Code & Subcodes w/ Description of Codes & Examples of Code \\
\hline Developmental Stage of TC & $\begin{array}{l}\text { Quarter One: Q1 } \\
\text { Quarter Two: Q2 } \\
\text { Quarter Three: Q3 }\end{array}$ & \\
\hline Subject Matter of Lesson & $\begin{array}{l}\text { English Language Arts (ELA) } \\
\text { Mathematics } \\
\text { Social Sciences/History } \\
\text { Science (Chemistry, Physics, Biology) } \\
\text { Arts } \\
\text { Physical Education }\end{array}$ & \\
\hline $\begin{array}{l}\text { Focus of Feedback: Alignment with } \\
\text { Prioritized Skills }\end{array}$ & 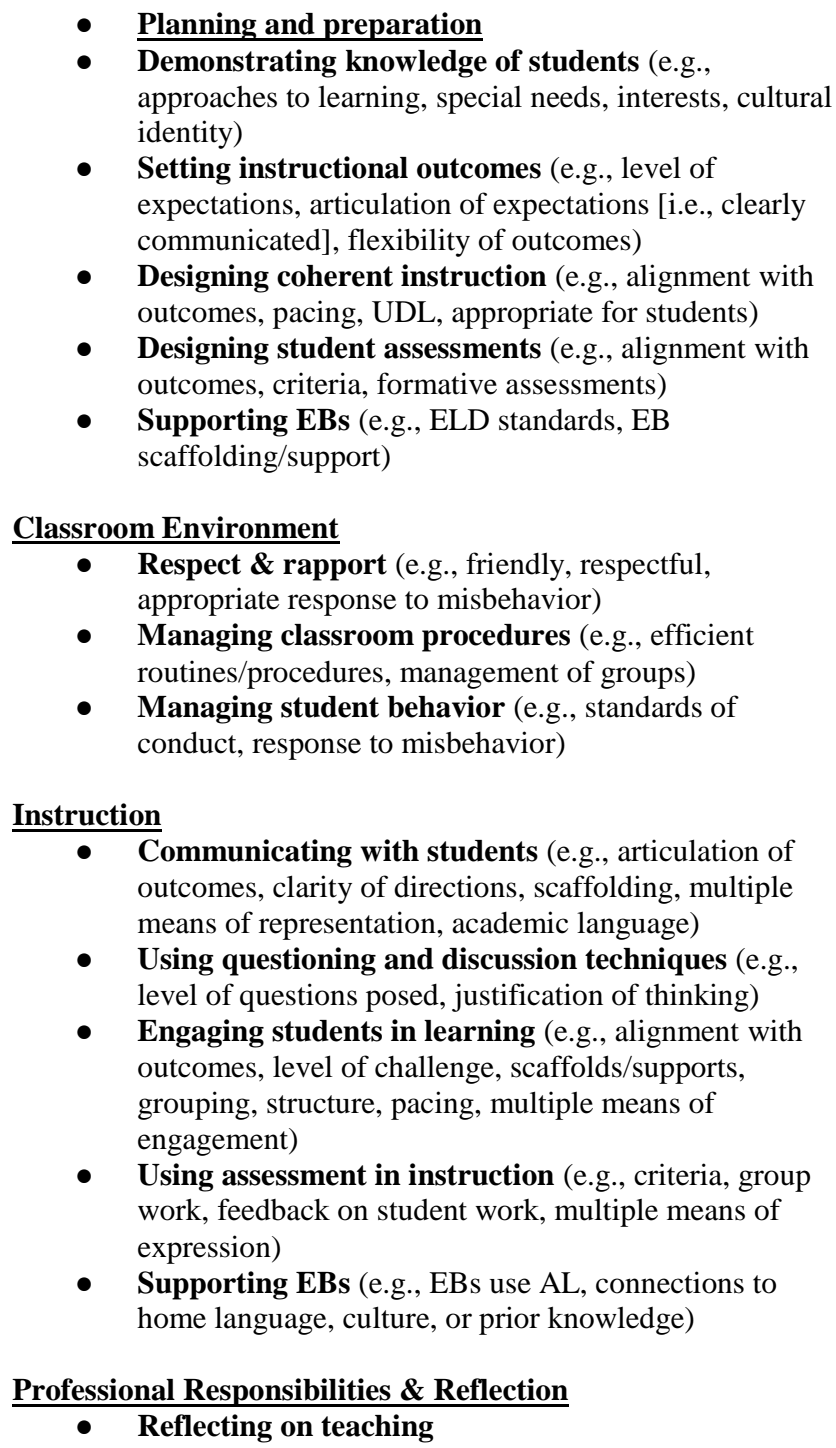 & $\begin{array}{l}\text { Planning and preparation (you } \\
\text { were well prepared; you clearly } \\
\text { knew the material) } \\
\text { Demonstrating knowledge of } \\
\text { students (When planning your } \\
\text { lesson, you implemented } \\
\text { instructional strategies that } \\
\text { would support all learners) } \\
\text { - Setting instructional outcomes } \\
\text { (Be careful of the wording of } \\
\text { your learning outcome on your } \\
\text { lesson plan. How might you } \\
\text { make it more student-friendly?) } \\
\text { Designing coherent instruction } \\
\text { (I noticed that your learning } \\
\text { outcome did not align with your } \\
\text { instructional activities) } \\
\text { Designing student assessments } \\
\text { (In your lesson plan, the rubric } \\
\text { you provide for assessing } \\
\text { students' contributions to class } \\
\text { discussion will help students to } \\
\text { understand your expectations) } \\
\text { Supporting EBs (Don't forget } \\
\text { to include an ELD standard on } \\
\text { your lesson plan) } \\
\text { - Classroom Environment } \\
\text { - } \text { - } \\
\text { clascellent creation of a warm } \\
\text { Respect \& rapport (Smart idea } \\
\text { to greet students at the door as } \\
\text { they enter the classroom) } \\
\text { Managing classroom } \\
\text { procedures (Little instructional } \\
\text { time was wasted when } \\
\text { distributing activity materials; } \\
\text { using signals to get attention of } \\
\text { class; managing supplies } \\
\text { efficiently) }\end{array}$ \\
\hline
\end{tabular}


- Professionalism (e.g., attire, interactions with students, confidence)
Focus of Feedback: In addition to Prioritized Skills
- Content-specific feedback (feedback focuses on content knowledge of the subject matter)

- Use/Integration of technology (feedback focuses on efforts to incorporate technology into instruction)

- Project based learning (PBL) (feedback focuses on efforts to implement project-based learning)

- Co-teaching (CoT) (feedback focuses on collaborative efforts between CT and TC)

- Integrated Lesson (Literacy/Content Area; Math/Content Area) (feedback focuses on efforts to integrate literacy and/or math with other content area subjects)
- Managing student behavior (You reminded students to raise their hands before contributing to discussion)

- Instruction (nice job with the teaching)

- Communicating with students (At the beginning of the period, you read the learning outcome and reviewed the agenda)

- Using questioning and discussion techniques (You asked 15 recall questions and only 1 higher-level thinking question)

- $\quad$ Engaging students in learning (The pacing of the lesson seemed appropriate in maintaining student attention)

- Using assessment in instruction (Great use of checks for understanding throughout the lesson to see how students were progressing in the lesson)

- Supporting EBs (nice emphasis of academic vocabulary for English Learners)

Professional Responsibilities \& Reflection

- Reflecting on teaching (In our post-observation conference, you articulated the need for greater challenge in the lesson)

- Professionalism (confident teaching presence, confident interactions with students)

- Content-specific feedback (Be careful about how you define simile for your current definition may confuse students when learning about metaphor)

- Use/Integration of technology (Seamless integration of Chromebooks throughout the lesson)

- $\quad$ Project based learning (PBL) (Great use of an entry event when rolling out the project)

- Co-teaching (CoT) (Seamless transitions when team teaching with your co-teacher)

- Integrated Lesson (Content and Language/Literacy objectives embedded in instruction)

- Opinion-based (Checking for understanding was ineffective; Great job!) 


\begin{tabular}{|c|c|c|}
\hline & $\begin{array}{l}\text { interpretive and/or subjective feedback and/or } \\
\text { motivational statements; general feedback that is not } \\
\text { specific to the particular lesson observed; feedback is } \\
\text { "rubber-stamped" and could be used from one } \\
\text { observation to the next) } \\
\text { - Evidence-based and/or specific (feedback is grounded } \\
\text { in a record of what was observed; objective/free of bias } \\
\text { or opinion; this type of feedback might include direct } \\
\text { quotes, detailed description of teacher and student } \\
\text { actions and behaviors; quantifiable) }\end{array}$ & $\begin{array}{l}\text { - Evidence-based (Five students } \\
\text { raised their hands when } \\
\text { responding to the question of } \\
\text { "What caused the feud") }\end{array}$ \\
\hline Positioning & $\begin{array}{l}\text { - Evaluator/Judge (focus of feedback is on what was } \\
\text { done right and/or wrong; often is grounded in opinion- } \\
\text { based feedback) } \\
\text { Calibrating (feedback aligns with a prioritized skill } \\
\text { and is more of a narrative/recall of what occurred in the } \\
\text { observation connected to this prioritized skill [there } \\
\text { might be some evaluative language included but the } \\
\text { emphasis is on the narrating evidence for what the TC } \\
\text { did) } \\
\text { Consulting (feedback proposes goals and steps for } \\
\text { improvement; grounded in suggestions } \\
\text { Collaborative Coaching (feedback is grounded in } \\
\text { building TC capacity for self-coaching and self- } \\
\text { reflection) }\end{array}$ & $\begin{array}{l}\text { Evaluator/Judge (Didn't do the } \\
\text { hand signal correctly; excellent } \\
\text { management [with no supporting } \\
\text { evidence] } \\
\text { Calibrating (Lesson began with } \\
\text { teacher modeling) } \\
\text { Consulting (you could do...you } \\
\text { might consider...; I'd suggest } \\
\text { beginning with a mentor text) } \\
\text { Collaborative Coaching (Do } \\
\text { you think all of the children were } \\
\text { able to hear the directions? What } \\
\text { other ways could you have } \\
\text { represented the information to } \\
\text { the students?) }\end{array}$ \\
\hline Emphasis of Feedback & $\begin{array}{l}\text { - Praise (feedback describes what went well/what } \\
\text { effective practices were implemented) } \\
\text { - Area of Growth (feedback identifies an area of } \\
\text { growth) }\end{array}$ & $\begin{array}{l}\text { Praise (positive evaluative } \\
\text { adjectives to describe practices) } \\
\text { Area of Growth (negative } \\
\text { evaluative adjectives to describe } \\
\text { practices or lack thereof; phrased } \\
\text { as suggestions to improve } \\
\text { practice) }\end{array}$ \\
\hline
\end{tabular}

Appendix B

MSTEP Teacher Candidate Observation Tool

\begin{tabular}{|l|l|}
\hline Teacher Candidate: & Date: \\
\hline Cooperating Teacher: & University Supervisor: \\
\hline School: & Grade Level: \\
\hline Lesson Topic: & Observation \#: \\
\hline
\end{tabular}

$\mathbf{1}=$ Did not Demonstrate $/ \mathbf{2}=$ Partially Demonstrated $/ \mathbf{3}=$ Demonstrated $/ \mathbf{4}=$ Demonstrated with Distinction 


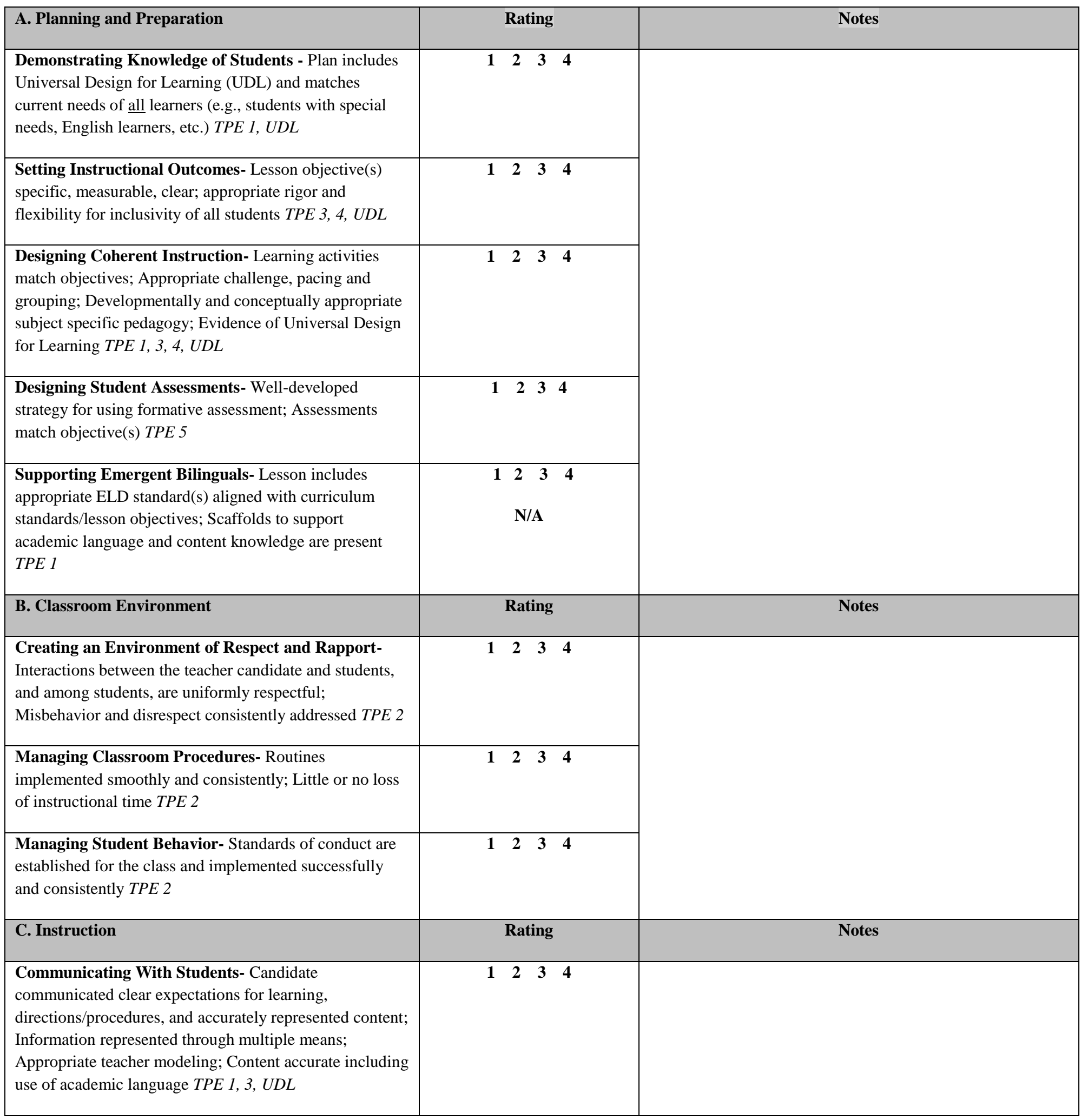




\begin{tabular}{|c|c|c|}
\hline $\begin{array}{l}\text { Using Questioning and Discussion Techniques- Variety } \\
\text { of questions promote student thinking; Most students } \\
\text { engaged/involved in discussions TPE } 5\end{array}$ & $\begin{array}{llll}1 & 2 & 3 & 4\end{array}$ & \\
\hline $\begin{array}{l}\text { Engaging Students in Learning- Students engaged, } \\
\text { guided and supported through multiple means; Activities } \\
\text { align with objectives; Appropriate challenge, grouping } \\
\text { and pacing to meet needs and abilities of students; Lesson } \\
\text { has clear structure (anticipatory set, closure) TPE 1, UDL }\end{array}$ & $\begin{array}{llll}1 & 2 & 3 & 4\end{array}$ & \\
\hline $\begin{array}{l}\text { Using Assessment in Instruction- Candidate monitors } \\
\text { student learning, assesses objective(s) and provides } \\
\text { timely and appropriate feedback including reinforcement; } \\
\text { Students provided with multiple means of action and/or } \\
\text { expression TPE 5, UDL }\end{array}$ & $\begin{array}{llll}1 & 2 & 3 & 4\end{array}$ & \\
\hline $\begin{array}{l}\text { Supporting Emergent Bilinguals- ELs/EBs actively } \\
\text { participate; Opportunities provided for language } \\
\text { production and content engagement; Tasks draw on home } \\
\text { language/culture/prior knowledge TPE } 1\end{array}$ & $\begin{array}{llll}1 & 2 & 3 & 4 \\
& \text { N/A }\end{array}$ & \\
\hline D. Professional Responsibilities - Reflection & Rating & Notes \\
\hline $\begin{array}{l}\text { Reflecting on Teaching- Candidate accurately assesses } \\
\text { the effectiveness of lesson; Identifies specific ways lesson } \\
\text { might be improved TPE } 6\end{array}$ & $\begin{array}{llll}1 & 2 & 3 & 4\end{array}$ & \\
\hline $\begin{array}{l}\text { Professionalism- Candidate demonstrated } \\
\text { professionalism - dress, punctuality, confidence, } \\
\text { responsive to feedback, etc. TPE } 6\end{array}$ & $\begin{array}{llll}1 & 2 & 3 & 4\end{array}$ & \\
\hline
\end{tabular}

\section{Evidence:}

2 - 3 Strengths of this lesson include: 
Journal of Student Research (2017)

Volume 6, Issue 2: pp, 45-55

Research Article

2 - 3 Suggestions for improvement include: 